\title{
National approach for evaluation and control of wine safety: Guide to good hygiene practices for French wine industry
}

\author{
Aurélie Camponovo ${ }^{1}$ and Christophe Riou $^{2}$ \\ ${ }^{1}$ Institut Français de la Vigne et du Vin (IFV), Pôle Rhône-Méditerranée, Centre du Rosé, 83550 Vidauban, France \\ ${ }^{2}$ Institut Français de la Vigne et du Vin (IFV), Siège, Domaine de l'Espiguette, 30240 Le Grau-du-Roi, France
}

\begin{abstract}
The adaptation of wines to the market requirements have involved changes in wine making processes. Improved methods of analysis now allow to detect traces of compounds injurious for consumers' health. In collective imagination, wines remain born from traditional methods, pathogen free and, by extension, free of any health concern. Consumers now access easily to detailed information, and various media allow them to get a hold on the subject of wine safety. The contents encountered are sometimes alarming and create many questions enable to damage the image of the product. In order to support French wine makers facing the rise of this theme and answer European regulation, IFV has developed with French professional organizations a guide to good hygiene practices (GGHP) including hazard analysis for wine industry. The aim was to provide all companies a reference document approved by the French authorities and pool most of the principles of HACCP to limit the task of smaller businesses. The GGHP details essential good practices that have to be implemented by every company of wine industry, regardless its size and the kind of wine produced. It also describes hazard analysis and specific recommendations for each one and gives recommendations and tools to manage them.
\end{abstract}

\section{Introduction}

The evolution of wine consumption and the necessary adaptation of styles of product to the market requirements have involved changes in wine making processes. New inputs, materials and oenological practices have emerged. At the same time, the improvement of methods of analysis and wine composition knowledge allowed to detect compounds injurious for consumers' health. However, in collective imagination, wines remain born from traditional methods. Therefore, they are considered as pathogen free and, by extension, free of any health concern.

The profusion of media information and the development of social networks now allows easy access to detailed information. Consequently, media and consumers increasingly get a hold on the subject of wine safety. The involved media contents announcements are sometimes alarming and create many questions enable to damage the image of the product.

Concomitantly, European regulation has evolved both on risk analysis in general food sector and on wine-specific requirements.

In order to support French wine makers facing the rise of food safety, IFV (French institute of vine and wine) has developed with French professional organizations a guide to good hygiene practices (GGHP) including hazard analysis for wine industry [1].

The guide is dedicated to the wine sector: vine growers, private cellars, cooperatives, wholesalers, bottlers, service providers... It should help each company to assess the hazards of its own, define control measures to implement and justify them. This guide outlines the essential elements of control while allowing flexibility for small businesses as well as adaptations to maintain traditional methods. This paper details the organization of the French wine sector to draft the document, the method used and the validation procedure. It summarizes the result of the hazard analysis and develops several examples. At least, it describes the proactive approach developed in the sector throughout this work and the next steps planed.

\subsection{Products concerned}

This work was limited to wines and spirits. It doesn't concern fruit juices, concentrated musts vinegars or winebased drinks. Indeed, these products either have different chemical properties and stability or require different ingredients or processes.

The producers concerned may nevertheless apply the document to the steps included in the scope of the guide.The guide doesn't take more into account operators' safety.

This guide takes into account the hazards identified at the time of its publication date. Also, the winemaker should be attentive to emerging potential hazards, including consulting the updates of the guide.

The identified hazards were validated by the French control authority after evaluation by the French food safety authority.

\subsection{Regulations and references taken into account}

The recital 18 of regulation EC $\mathrm{n}^{\circ} 178 / 2002$ [2] states that "risk assessments should be undertaken in an independent, objective and transparent manner, on the basis of the available scientific information and data". 


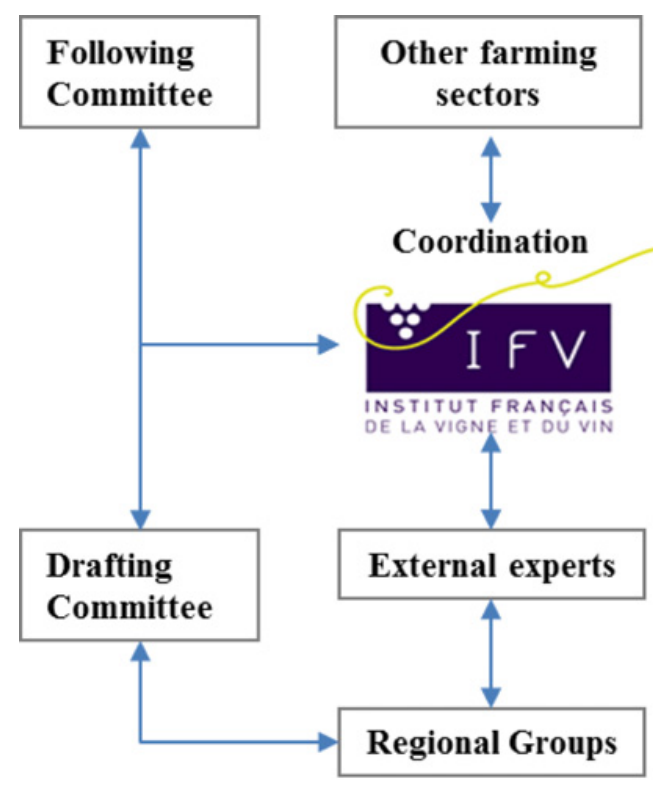

Figure 1. Consultation with the partners.

\subsubsection{Scientific and official documents}

This guide was written taking into account European Union regulations. Some specific French official references can also be encountered for regulations but also recommendations from ANSES (French food safety authority), DGCCRF (French control authority). In the absence of official reference or for additional information, OIV recommendations are also quoted.

\subsubsection{Technical documents}

The French technical institute, professional organizations, chamber of agriculture and other structures relating to wine sector make available many technical documents for producers. Some of them are quoted to help the reader to find examples or detailed and concrete information about precise subjects.

\subsubsection{Consumer's opinion}

Although the recital 18 preconize solid references the recital 19 précises that "It is recognized that scientific risk assessment alone cannot, in some cases, provide all the information on which a risk management decision should be based, and that other factors relevant to the matter under consideration should legitimately be taken into account including societal, economic, traditional, ethical and environmental factors...". In several cases as for plant product residues, the drafting committee chose to consider also consumer's opinion.

\section{Method and organization}

\subsection{Partnership}

In France, the wine sector's organization is very complex. IFV, the French Institute of Vine and wine had to form a group of experts of the sector (Fig. 1). We requested the participation of several regional professional organizations to cover different products and designations of origin in the drafting committee (Table 1). Some of these
Table 1. Partnership.

\begin{tabular}{|c|c|}
\hline \multicolumn{2}{|r|}{ Drafting committee } \\
\hline $\mathrm{BNIC}$ & $\begin{array}{l}\text { Bureau national interprofessionnel du } \\
\text { Cognac }\end{array}$ \\
\hline Castel & Société Castel \\
\hline CIVB & $\begin{array}{l}\text { Comité interprofessionnel des vins de } \\
\text { Bordeaux }\end{array}$ \\
\hline CIVC & $\begin{array}{l}\text { Comité interprofessionnel des vins de } \\
\text { Champagne }\end{array}$ \\
\hline CNIV & $\begin{array}{l}\text { Comité national des interprofessions des } \\
\text { vins d'appellation d'origine }\end{array}$ \\
\hline Johnson Diversey & Société Johson Diversey \\
\hline MHCS & $\begin{array}{l}\text { Société Moet Hennessy champagne } \\
\text { services }\end{array}$ \\
\hline UOEF & Union des oenologues de France \\
\hline VIF & $\begin{array}{l}\text { Syndicat des vignerons indépendants de } \\
\text { France }\end{array}$ \\
\hline \multicolumn{2}{|r|}{ Following committee } \\
\hline CNAOC & $\begin{array}{l}\text { Confédération nationale des producteurs } \\
\text { de vin et eaux-de-vie de vin à appella- } \\
\text { tions d'origine contrôlées }\end{array}$ \\
\hline DGAL & Direction générale de l'alimentation \\
\hline DGCCRF & $\begin{array}{l}\text { Direction générale de la concurrence, de } \\
\text { la consommation et de la répression des } \\
\text { fraudes }\end{array}$ \\
\hline FranceAgrimer & $\begin{array}{l}\text { Etablissement national des produits de } \\
\text { l'agriculture et de la mer }\end{array}$ \\
\hline ICV & Institut coopératif du vin \\
\hline INAO & $\begin{array}{l}\text { Institut national de l'origine et de la } \\
\text { qualité }\end{array}$ \\
\hline Inter-Beaujolais & $\begin{array}{l}\text { Union interprofessionnelle des vins du } \\
\text { beaujolais }\end{array}$ \\
\hline UMVIN & Union des maisons et marques de vin \\
\hline VIF & $\begin{array}{l}\text { Syndicat des vignerons indépendants de } \\
\text { France }\end{array}$ \\
\hline
\end{tabular}

experts were also members of the OIV commissions. During the drafting, regional groups were also formed to focus on particular points and we exchanged with other agricultural sectors and external experts when necessary. This work was followed by a following committee of concerned organisms less technical such a way they could be informed all along the drafting and give an opinion at any time.

\subsection{Hazard analysis method}

Each wine-maker has to conduct a hazard analysis.

\subsubsection{Method}

He can conduct his own analysis. In this case, the winemaker will have to justify with his own data the reasons why he identifies some hazard. To do so, he can use the information provided in this guide to implement HACCP principles. Example: implementation of new 
technologies, significantly modifying a process in response to customer requirements. This should allow all operators to adapt their safety organization to the oenological news and to the demands of their clients.

He can rely on the list of the hazards that should be controlled, given in this guide. This analysis was conducted by the national group to simplify the implementation of HACCP principles by companies.

A complete list of potential hazard based on scientific data but also media information or empiric knowledge was done and the level of risk was evaluated to get a list of compounds to monitor.

In this case, the operator will select the relevant hazards to his own farm, explaining his choice. If the winemaker can prove that he is not concerned with certain hazards, it will remove them from its list.

This should allow all operators to adapt the list of hazards to their own situation (process, organization, location ....).

\subsection{2. "Hazard by hazard" approach}

The hazard analysis is usually made step by step, by listing every potential hazard.

To facilitate the analyses, we choose to follow each hazard independently all along the process. This one that can vary depending on the region, the product or the wine-maker preference. This method allowed to take into account the diversity of processes for a national approach remaining readable. It was also a way to guide the discussions and to distribute the parts among the experts.

\subsubsection{Multiples analysis}

The hazard analysis was conducted on every potential hazard. For some of them, two analyses were done to take into account different kinds of consumers. It was the case for sulfites that can have both adverse effects on everyone over the acceptable daily intake [3] and potentially critical effects on allergic consumers [4].

\subsection{Validation procedure}

In France, the GGHPs are validated by the DGCCRF after opinion of the ANSES, The drafting is also corrected by the DGAL and the DGS. The final document is presented to the CNC before validation, and the official version is transmitted to European Union for information (Fig. 2).

\section{Results, discussion}

\subsection{Structure of the document}

The document contains three parts and many annexes. The first part describes the field of the guide and general recommendations as food safety management or traceability. The second part indicates the good hygiene practices that have to be applied by all the operators whatever their size or their kind of production. The third part describes the hazard analysis and critical control point (HACCP) principles applied to the wine sector and gives specific recommendations to control the risk. The annexes include toolboxes, examples of recording documents and technical sheets.

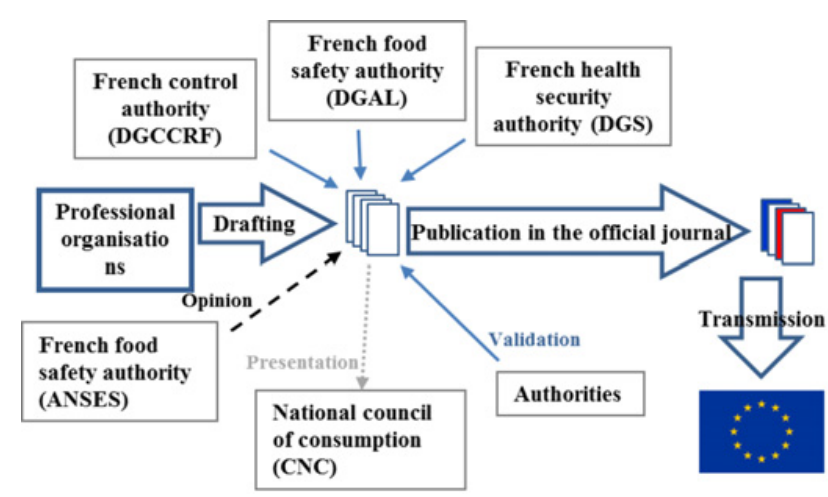

Figure 2. Official procedure of validation in France for guides to good hygiene practices.

Table 2. Compounds to monitor in wines according to the guide.

\begin{tabular}{|l|l|}
\hline \multirow{5}{*}{ Chemical } & Sulfites \\
\cline { 2 - 3 } & Cyanide derivatives \\
\cline { 2 - 2 } & $\begin{array}{l}\text { Heath exchange fluids monoethylene } \\
\text { glycol-based, diethylene glycol-based } \\
\text { or treated water } \\
\text { Maintenance products }\end{array}$ \\
\cline { 2 - 3 } Bead & Lead \\
\cline { 2 - 3 } Physical & Ethanal for intolerant consumers \\
\cline { 2 - 3 } Allergens & Plant-health products \\
\hline & Ochratoxin A \\
\hline & Broken glass \\
\cline { 2 - 3 } & $\begin{array}{l}\text { Pressure containers } \\
\text { Oenological practices and processes } \\
\text { egg or milk-bases for allergic con- } \\
\text { sumers }\end{array}$ \\
\cline { 2 - 2 } & Sulfites $>10$ mg/L \\
\hline
\end{tabular}

\subsection{Result of hazard analysis}

\subsubsection{Compounds to monitor}

The third part of the document gives the results of the hazard analysis and the list of the hazard that should be monitored (Table 2). For each of them, a detailed sheet and a toolbox containing examples of control measures is given in annex.

\subsection{Preconizations and tools}

\subsubsection{Monitoring scales}

Monitoring measures were preconized at different scales according to the hazard analyzed. For example, companies' scale for broken glass or collective scale for ochratoxin A or plant health-products.

\subsubsection{Decision tree}

A decision tree is proposed to help the reader to class the measures as good practices that should be applied before hazard analysis, operational good practices that allow to control a specific hazard, and critical control points for which apply more requirements of monitoring before the 
exit of the product. The guide specifies that the decision tree is indicative. In case of blocking, it doesn't replace an explanation that makes sense.

\subsubsection{Recording sheets}

Examples of recording sheets are given in annex. These documents have been chosen to be disseminated because they were already used on the field in some regions and have proved their efficiency.

\subsection{Examples of approaches}

\subsubsection{Environment of the site}

To answer to the exigency of the Regulation (EC) $\mathrm{n}^{\circ} 852 / 2004$, recommendations were done about the environment of production sites that should be free from any contamination. In some cases the producer couldn't know the source of such contaminations and have no mean to control it. We can imagine for example the neighborhood of industries that could generate metallic trace element, dioxins or radioelements in case of accident. In these cases, a particular exceptional and global management applies and should be driven by the authorities. Such recommendations have been done in dialogue with the other agricultural sectors. For radioelements, a specific tool have been created in 2012 in the agricultural sector in cooperation with the nuclear safety institute of radioprotection.

\subsubsection{Pathogen survival and foodborne diseases transmission}

The first characteristic of wine sector when talking about food safety is the absence of pathogens and foodborne illness propagation.

Paradoxically, despite the evidence of this assertion and the unanimity of the scientific and technical round table, few data were immediately available on this point.

The best arguments in favor of wine safety are its alcohol content, its acidity and its content in phenolic compounds. Studies are still carried out on various pathogens [5-7].

In order to apply the same method as for the other potential hazards, we stove to explore specifically sources as Eurosurveillance that is the Europe's journal on infection disease epidemiology, prevention and control. Searching "wine" anywhere in the text of the articles of Eurosurveillance 19/07/2016 gives eight results. Seven are about foodborne diseases. In four of them [8-11], the wine is mentioned as an ingredient of the meal or as the associated beverage but wasn't responsible of the disease. In one study, it was reported as an agent limiting the negative health impact of the disease [12]. The three other cases are about diseases indirectly related to alcohol consumption threw impact on the behavior enhancing the risk of sexually transmitted disease [13-15].

\subsubsection{Ethanol}

In the hazard analysis, the issue of ethanol was also addressed. Maybe ethanol in wine should be considered as a chemical hazard? This question is pertinent for society but it makes no sense in the context of HACCP analysis because it is a part of the definition of the product and, as such, it can't and mustn't be avoided. Another factor distinguishing ethanol from contaminants is that the consumer is aware of its presence in wine and can even consider it as a qualitative element of the beverage. Therefore, a short paragraph specifies this point in the guide and gives a link to Vin et Société website information. This organization created by the French wine sector is engaged for information on alcoholic beverages and prevention against excessive consumption.

\subsubsection{Genetically modified organisms}

GMO have not been treated because they are forbidden in wine growing in France and in Europe.

\subsubsection{Mycotoxins}

Ochratoxin A was identified as a compound to monitor in French vineyards. For a proactive approach, the possibility of emerging mycotoxins is currently being studied by IFV in a project financed by the French agricultural ministry.

\subsubsection{Materials in contact}

The wine sector had previously had to deal with the subject of materials [16]. So, recommendations valid for every materials were given in the document. During the drafting, we observed the emerging of the question of materials in contact with food linked to endocrine disruptors as bisphenol A or phthalates.

The wine sector ought to adjust recommendations on these new subjects as soon as enough data is available for wine, following current experimentations.

Waiting for the next update of the GGHP, these elements will be provided to the producers on technical sheets diffused by IFV and its partners.

\subsubsection{Plant protection products residues}

A global hazard analysis was made on pesticides, taking into account the most toxic substances. On longer term, it should be desirable to rationalize this analysis applying it for each active substance. Today, analyses of plant protection residues levels, realized on marketed wines either by control authorities or wine professional organizations, are always lower than the European maximum residue limits (MRL's).

According to the first opinion of the French food safety agency (ANSES), the level of risk is low, but the consumer's opinion, who tends to worry about the presence of traces, even conform to regulation, must be considered. This decision also responds to the recital 19 of the regulation EC n ${ }^{\circ} 178 / 2002$ [2]: "It is recognized that scientific risk assessment alone cannot, in some cases, provide all the information on which a risk management decision should be based, and that other factors relevant to the matter under consideration should legitimately be taken into account including societal, economic, traditional, ethical and environmental factors and the feasibility of controls". 


\section{Conclusions, prospects}

\subsection{Diffusion}

The publication of this document will be formalized by the authorities in the French authenticated electronic official journal.

It will be disseminated online by IFV which also studies the relevance and the feasibility of an interactive version that would allow to explore the document containing more than 200 pages from an illustrated presentation of about 15 slides.

\subsubsection{Specific adaptations}

Several winemaking regions provide local adaptations in order to pool more information for their products in shorter documents and add specific recommendations.

Writing specific parts for organic farming was considered and it was decided to make no specifications. Indeed, the French technical institute of organic farming (ITAB) would be more competent to adapt the recommendations in a specific guide.

\subsubsection{Update}

The guide to good hygiene practices is an inventory at the date of its validation. To keep an efficient tool, the wine sector wishes to update the document every 3 years. Regulatory evolutions will be taken into account but also demands from the field following the publication of this new version. The results of current studies will also provide new recommendations.

\subsection{Momentum generated}

In parallel with drafting the guide, since 2006, a national network about wine safety, constituted of members of the different committees and other experts begun to form to talk about emerging compounds. These potential hazards (endocrine disruptors, nanomaterials...) quoted in media or last scientific publications and on which we don't have much background for wine have to be analyzed along the way. This led IFV to start experimentations to improve the knowledge on wines for some phtalates or mycotoxins.
Today, the national network has a proactive "bottom up" approach, collecting the questions from the field to analyze the associated risk. In complement, a scientific and media monitoring allows to cross technical interrogations with the scientific advances and current issues.

\section{References}

[1] Comité de rédaction du guide de bonnes pratiques d'hygiène, Guide de bonnes pratiques d'hygiène, filière vins, DILA, Direction de l'information légale et administrative, Paris, 218, To be published

[2] European Parliament \& Council of the European Union, Regulation (EC) $\mathrm{n}^{\circ} 178 / 2002$, European Commission, 02002R0178-20140630, 2002

[3] EFSA, EFSA Journal, 14, 4438 (2016)

[4] D.A. Moneret-Vautrin, G. Kanny, L. Parisot, Rev. Fr. Allergol., 41, 696 (2001)

[5] E. Mingo, J.M. Silván, A.J. Martinez-Rodriguez, LWT - Food Sci. Technol., 68, 418 (2016)

[6] M. Daglia, A. Papetti, P. Grisoli et al., J Agric Food Chem, 55, 5038 (2007)

[7] N. Boban, M. Tonkic, D. Budimir et al., J Food Sci, 75, M322 (2010)

[8] Meusburger S., Reichert S., Heibl S. et al., Euro Surveill., 11, 3097 (2006)

[9] T. Inns, K. Foster, R. Gorton, Euro Surveill., 15, 19704 (2010)

[10] M. Insulander, B. De Jong, B. Svenungsson, Euro Surveill., 13, 19071 (2008)

[11] C. Hadjichristodoulou, E. Nikolakopoulou, K. Karabinis et al., Euro Surveill., 4, 69 (1999)

[12] A.M. Correia, G. Gonçalves, A. Gomes et al., Euro Surveill., 7, 2195 (2003)

[13] C. Larsen, G. Pialoux, D. Salmon et al., Euro Surveill., 13, 18888 (2008)

[14] K. Haar, V. Bremer, C. Houareau et al., Euro Surveill., 18, 20562 (2013)

[15] A. Tripathi, K. Rüütel, R.D. Parker, Euro Surveill., 14, 19429 (2009)

[16] IOV, Scientific and technical notebook: lead, IOV, Paris, 142, 1995 